\title{
A case study of the Mexican avocado industry based on transaction costs and supply chain management practices*
}

(Estudio de caso de la industria del aguacate en México basado en los costos de transacción y las prácticas administrativas de la cadena de suministro)

\author{
Jaime Arana Coronado,** Jos Bijman, *** Onno Omta,**** \\ and Alfons Oude Lansink*****
}

\begin{abstract}
The present study is based on transaction cost economics and supply chain management to analyze how the adoption of supply chain management practices in the Mexican avocado industry reduces the transaction costs between producers and packers. Two sources of information are used: interviews from different stakeholders and reviews of documents. Conclusions show that the adoption of three practices, product standardization, supplier partnership, and information exchange, has been a solution when challenges such as enhancing quality, obtaining reliable supply, and coordinating supply and demand conditions, are faced in a supply chain.
\end{abstract}

Keywords: product standardization, supplier partnership, information exchange, collaboration, Persea americana Mill.

JEL classification: D21, D23, D74, D81.

\section{RESUMEN}

El presente estudio, con base en las nociones de costos de transacción y gestión de la cadena de suministro, analiza cómo la adopción de prácticas administrativas en la cadena de suministro reduce los costos de transacción entre productores y empacadores en la industria del aguacate en México. Se usan dos fuentes de información: entrevistas a distintos actores de la industria y revisión de documentos. Las conclusiones muestran que la adopción de tres prácticas (estandarización del producto, proveedor asociado e intercambio de información) han sido una solución ante desafíos como la mejora en la calidad, la certidumbre en la oferta del producto y una mejor coordinación entre oferta y demanda.

Palabras clave: estandarización del producto, proveedor asociado, intercambio de información, colaboración, Persea americana Mill.

Clasificación JEL: D21, D23, D74, D81.

\footnotetext{
* Fecha de recepción: 30/04/2013. Fecha de aprobación: 22/10/2014.

** Researcher and professor in Finance and Business Economics at the Colegio de Postgraduados. E-mail: jarana@colpos.mx.

*** Associate professor in Business Administration at Wageningen University.

**** Chaired professor in Business Administration at Wageningen University.

***** Chaired professor in Business Economics at Wageningen University.
} 


\section{INTRODUCTION}

Analysis of agrifood supply chains originating from developing countries has focused on aspects such as quality and safety of products and reliability of supply (Reardon and Barrett, 2000; Ruben et al., 2007). Consistent product quality and compliance with complex food safety and phytosanitary standards are required when exporting to the highly demanding markets in North America and Europe. Particular supply chain management practices, such as product standardization, supplier partnership, and information can be used to enhance quality, guarantee safety, and improve coordination between supply and demand conditions (Van der Vorst, Da Silva and Trienekens, 2007).

For Mexican avocado (Persea americana Mill.) producers, the United States has become the major foreign market, but also a market with high requirements in terms of product quality and phytosanitary conditions. Since 1997, the US market has been opened for avocado from Mexico, but only under strict quality control. In order to raise product quality to comply with the US quality standards, the actors in the avocado supply chain have introduced new technical and organizational solutions. Packers, as the main interface between producers and customers, have played a dominant role in the design of safety norms as well as reliable and sustainable sanitary supervision systems (Stanford, 1998). In addition, packers have implemented supplier partnerships to obtain reliable supply. Finally, systems of information exchange have been implemented, firstly to obtain better information on consumer demand so as to improve the planning of packaging and distribution processes, and secondly to be able to communicate with the producer about quality requirements. Thus, the strengthening of the packer-producer relationship has enabled an enhancement of the coordination of both quality and quantity in the Mexican avocado supply chain. Under the relevance of these practices, we pose the following question: how have the supply chain management practices implemented by the packers facilitated to enhance product quality, create reliable supply and improve the planning of packaging and distribution processes?

To address this question, we propose to present an analysis of the technical and organizational solutions packers in the Mexican avocado industry have introduced to deal with the main supply chain challenges. In this respect, the paper holds the following objectives: first, to indicate the main challenges in the Mexican avocado industry from a supply chain management perspective; and second, to analyze how the adoption of supply chain management practices 
(technical and organizational solutions) in the Mexican avocado industry reduces the transaction costs between producers and packers.

The paper is structured as follows: First section presents the theoretical framework consisting of transaction cost economics and supply chain management. Next section describes the methodology that has been used. Third section describes the Mexican avocado industry, and after that, it continues with a more detailed look at the packers. Then, in the following section, the main supply chain challenges are introduced. In fifth section, the technical and organizational solutions are identified. Finally, the conclusions are presented.

\section{THEORETICAL FRAMEWORK}

The current research makes use of two theoretical approaches for explaining technical and organizational solutions in the Mexican avocado chain, Transaction Cost Economics (TCE) and Supply Chain Management (SCM). TCE, as developed by Williamson $(1979 ; 1985)$ and others, explains that transaction costs are the costs of undertaking an exchange between buyers and sellers, and which could be too high under certain conditions (Grover and Malhotra, 2003). In those cases, organizing economic transaction within collaborative arrangements might be superior to organizing it as a market based model in the supply chain (Power, 2008). SCM is a management approach that seeks to explain how by mean of Supply Chain Management Practices, collaboration between partners can improve coordination and competitiveness in the supply chain (Simatupang and Sridharan, 2004).

\section{Transaction Cost Economics}

The earliest work on transaction cost is attributed to Ronald Coase who explained that the primary reason why firms exist in a specialized exchange economy is not because of technological factors but because "there is a cost of using the price mechanism" (Coase, 1937, p. 391). Other authors such as Baumol (1952) and Tobin (1956) also refer how transaction costs, measured as brokerage fee, influence the money holding of individuals. TCE, as one approach within the broader field of New Institutional Economics, identifies three sources of transaction (Rindfleisch and Heide, 1997): safeguarding specific assets, adaptation of the transaction to changing conditions, and performance evaluation. Safeguarding occurs when a firm deploys specific assets and may be opportunistically exploited 
by the partner (Joskow, 1985). The adaptation or coordination is the cost of exchanging information and incorporating that information into the decision process $^{1}$ (Grover and Malhotra, 2003) when changing circumstances are present. The third source of transaction costs is difficult performance evaluation. It arises when a firm has difficulty assessing the contractual compliance of its exchange partners, in other words, when there is behavioral uncertainty.

Transaction costs are directly related to all the three sources and may arise in the form of costs that would include creating safeguard costs; screening, negotiation, selection, communication, and co-ordination costs (ex-ante costs); and measurement costs (ex-post costs) (Grover and Malhotra, 2003).

\section{Supply Chain Management}

Supply Chain Management Practices occur when two or more partners share the responsibility of exchange common planning, management, execution, and performance measurement information (Barratt and Oliveira, 2001). Thus, when Supply Chain Management Practices are adopted, parties may expect to realize potential benefits (Power, 2008).

The practice of product standardization has mostly been used to implement a strategy of cost reduction or increased flexibility (Van der Vorst, Dijk and Beulens, 2001). In the agrifood sector, the practice of product standardization consists of a number of activities aimed at increasing product quality and homogeneity, enhancing food safety, complying with private quality standards (Hammoudi, Hoffmann and Surry, 2009). Product standardization includes the activities of inspection and certification.

The second practice, supplier partnership, deals with the relationship between two independent entities in the supply chain to achieve objectives such as increased financial and operational performance through reductions in total costs, reductions in stocks throughout the supply chain, and increased levels of coordination. In the agrifood sector, supplier partnership, developed by processors and packers with their suppliers, has been presented as an instrument to improve and maintain product quality and reliable supply (Kannan and Tan, 2005; Van Plaggenhoef, 2007). Important elements of supplier partnership

\footnotetext{
${ }^{1}$ Adaptation problem has two dimensions: autonomous adaptation, where transaction partners respond independently to variables like price; and coordinated adaptation to disturbances which require a coordinated response (Williamson, 1991).
} 
are commitment and trust (Duffy and Fearne, 2004; Pyke and Johnson, 2003). Commitment is the willingness of each partner to exert effort on behalf of the relationship (Pyke and Johnson, 2003). Trust is the willingness to rely on a trading partner in whom one has confidence (Kumar, Scheer and Steenkamp, 1995).

The third practice, information exchange, consists of generating and sharing information among the supply chain partners. Information exchange consists of two activities (Barrat and Oliveira, 2001; Kulp, Ofek and Whitaker, 2003): the generation of information to forecast demand and plan activities, and sharing this information to upstream supply chain members. Spriggs, Hobbs and Fearne (2000) distinguish two levels of information exchange. First, simple information such as product specifications, prices, and delivery schedules. Second, more complex information may be exchanged and incorporated into the decision process; for example, requirements for adoption of product quality and safety standards according to market preferences and regulations (Raynaud, Sauvee and Valceschini, 2005).

\section{Combining Supply Chain Management and Transaction Cost Economics}

Supply chain management practices can be considered as technical and organizational solutions to the problem of high transaction costs. Insofar as the practices are organizational solutions, such as the establishment of a supplier-buyer partnership, they fit in the TCE model, which predicts that a different organizational structure will be chosen when transaction costs increase.

The issue of standardization is ambiguous. One would expect that standardization will lead to a reduction of transaction costs because products become more homogeneous and buyers therefore need to put in less effort into screening, selecting, and negotiating (Grover and Malhotra, 2003). Additionally, certification communicates to external parties that a supplier has a documented quality in place, and thus can reduce the monitoring transaction costs (Holleran, Maury and Zaibet, 1999). However, when the initial introduction of standards requires a substantial effort on the part of the buyers to inform all (potential) suppliers about the new product requirements, short-term transaction costs go up (Raynaud, Sauvee and Valceschini, 2005). In addition, buyers may incur costs in helping suppliers to adjust their business processes. This problem of coordination (or coordinated adaptation) may be solved by public intervention in which government develops, introduces, and enforces new standards. 
A supplier partnership can be considered as a hybrid governance structure, chosen in situations where product quality and reliability of supply are important. A supplier partnership provides opportunities for lower cost information exchange, which is needed for coordinated response to high quality requirements. When this partnership is developed, the cost of coordination and the cost related to opportunism can be mitigated (Power, 2008). Mechanisms such as commitment trust (Das and Teng, 1998), and continuity expectations (Artz and Brush, 2000) can increase the common interest, and therefore, the collaboration between parties and reduce the transaction costs related to asset specificity (Dyer and Singh, 1998).

Enhanced information exchange is a typical solution to the uncertainty problem. Uncertainty in consumer demand, as a form of environmental uncertainty, can be reduced by collecting and processing market information (Noordewier, John and Nevin, 1990). Having this information can reduce the cost of stocks, the cost of misalignment between quality supplied and quality demanded, and the cost of finding the proper market. Improved information exchange between two partners can also reduce behavioral uncertainty. Being able to measure the exact quality of the product, for instance through improved measurement techniques, reduces the chance of opportunistic behavior by the partner. Finally, exchanging more and better information is also a solution to the problem of adaptation or coordination (Grover and Malhotra, 2003).

\section{Methodology}

This case study is based on two sources of information: interviews and reviews of documents. Interviews were carried out with different actors in the Mexican avocado industry as well as with representatives of research institutions and the government. These interviews were conducted between July and September 2009, in the state of Michoacán, México. To get a good overview of the industry and its developments, different stakeholders were interviewed: five producers, four packers, two traders, two packers' associations, and three representatives of the Mexican government. The representatives of the companies were chosen from the three main avocado producing municipalities: Uruapan, Peribán, and Tancítaro. Finally, differences in company size were included by interviewing managers from small, middle, and large enterprises.

A list of interview topics was used for all interviews (see Appendix). It considered broad information with respect to the structure and performance of 
the Mexican avocado industry, market characteristics, transactional problems, supply chain management practices, and governance structure. In addition to interviews, documents containing information about natural conditions, marketing channels, organizations, and technologies used were gathered from governmental institutions related to the avocado industry (e.g., Dorantes, Parada and Ortiz, 2004; Evans and Nalampang, 2006; Ramos, 2007; Sánchez, 2007).

\section{DESCRIPTION OF THE MEXICAN AVOCADO INDUSTRY}

\section{Physical conditions in Michoacán, México}

Michoacán is the principal avocado region in México (Sánchez, 2007). While it has good natural and geographical conditions to produce avocado almost all year-round (Ramos, 2007), the main harvesting period is between October and March. The majority of avocado orchards are located on elevations between 1 600 and $2200 \mathrm{~m}$, where there is a humid climate with abundant rain in summer and winter and temperatures ranging from 16 to $18^{\circ} \mathrm{C}$ during the coldest months and from 21 to $25^{\circ} \mathrm{C}$ during the warmest ones. Soils are rich in organic materials and the length of time from bloom to harvest is 8 to 14 months (Ramos, 2007). The main variety grown is the Hass (Persea americana Mill.), which is the most popular variety in the world. When the fruit is ripe, it can be maintained on the tree for several months without any harmful effects, and when it is harvested, its shelf life is approximately six weeks under good conditions (Dorantes, Parada and Ortiz, 2004).

\section{Production and producers}

The Mexican avocado sector annually generates a harvested product value of more than USD 700 million, while providing 42000 permanent and 31000 temporal jobs (Ramos, 2007). Most of the Mexican avocado production is concentrated in Michoacán, annually producing more than 800000 tons, on approximately 75800 hectares, by around 11700 producers (Sánchez, 2007). Five municipalities host $72 \%$ of the cultivated area and $66 \%$ of avocado producers: Tancítaro, Uruapan, Tacámbaro, San Juan Nuevo, and Peribán. Producers in these municipalities have between 5.2 and 8.5 hectares of orchard, yielding 10.5 tons/ hectare. However, more than $71 \%$ of the orchards are considered as small property with a size smaller than ten hectares, and most of them are characterized by 
lack of compliance with the phytosanitary requirements, no investments in fertilization, and no irrigation systems. Studies done in the avocado sector in Michoacán indicate that small size producers have no business orientation and have a strong limitation to capitalize the orchard (Sánchez, 2007).

\section{National and International Markets}

Mexico is the world leader in production, consumption and export of avocado (Dirección General de Industrias Básicas, 2012; FAOSTAT, 2013). More than 95\% of all production is consumed fresh; the other $5 \%$ is processed into avocado pulp and frozen guacamole paste, avocado oil, and frozen sliced avocado (Sánchez, 2007). The main export market for fresh avocado is US (importing $16 \%$ of total production) (Dirección General de Industrias Básicas, 2012). Exports to the US market have grown substantially over the last decade (Graph 1). Other export markets are Japan, Central America, Canada, and Europe, together accounting for almost $10 \%$ of production. In the US market, Mexican avocados compete with fruit from California and from Chile. Californian avocado has a $60 \%$ share of the US market, México 25\%, and Chile 15\% (FAOSTAT, 2013).

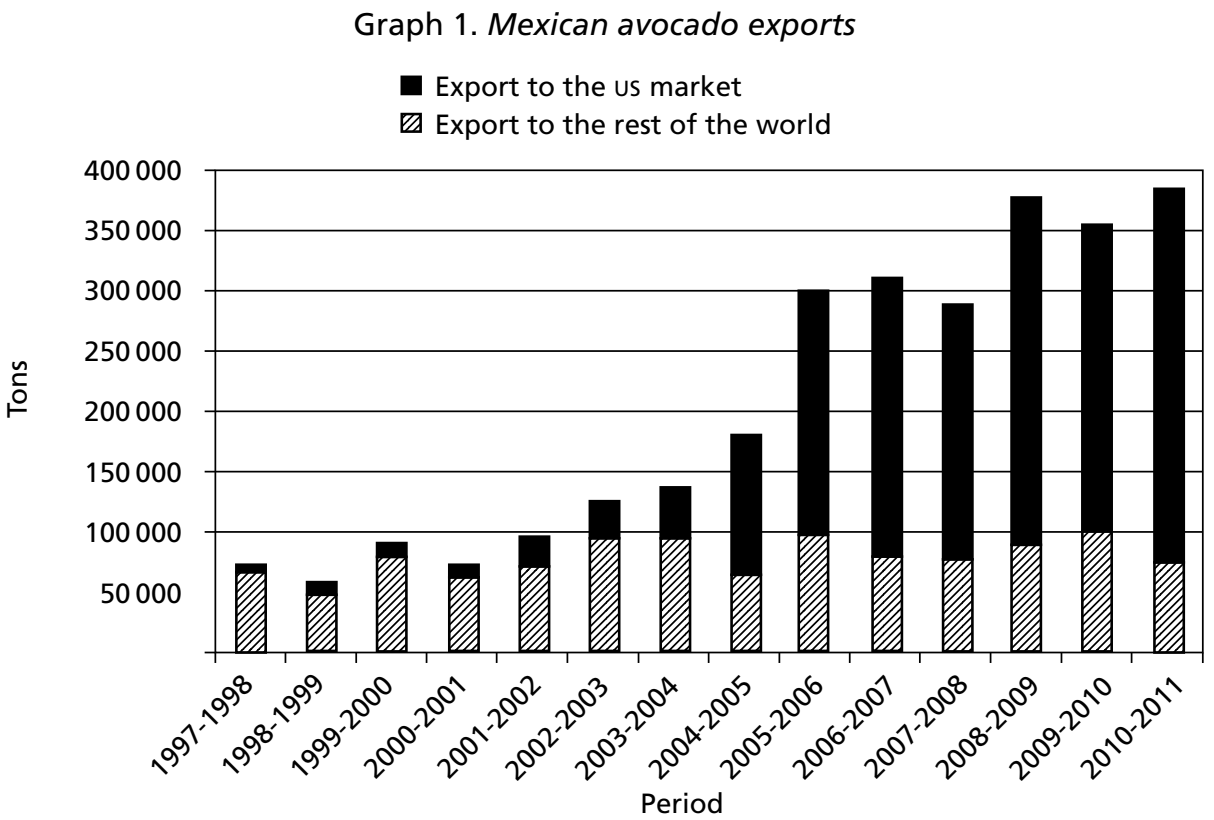

Source: Sánchez (2007). SAGARPA (2013). 
A new configuration of the Mexican avocado industry has developed since the non-tariff barriers that prohibited Mexican fresh avocado exports to the US market ${ }^{2}$ were eliminated ${ }^{3}$ and phytosanitary regulations were introduced (Ortiz, 2007; Sánchez, 2007). Nowadays, two markets can be identified: a national market for low quality avocado, and an international market for high quality avocado. Some $70 \%$ of total production is consumed domestically, and $30 \%$ is exported (Dirección General de Industrias Básicas, 2012, FAOSTAT, 2013). International markets demand fulfillment of food safety conditions, phytosanitary conditions, and product with larger size than domestic markets. Fruits not meeting the minimum export quality standards are sold at the national market or go into the processing industry. As of 2005, more than half of all avocado producers comply with the phytosanitary requirements.

Chart 1 shows the two main marketing channels and the packers supplying the channels. National packers target the domestic market, commercializing $44 \%$ of all the Mexican avocados. The other $56 \%$ is commercialized by export-oriented national packers and by export transnational packers. The latter are foreign (mainly US) owned packer companies. These transnational companies as well as some of the export national packers are integrated packing and trading companies (as indicated by the dark box in Chart 1), selling directly to foreign supermarkets. ${ }^{4}$

Producers selling in these different marketing channels have different characteristics, such as choice of quality standard, and linkages to particular packaging companies (Chart 2). The international channel is dominated by producers that hold a certificate indicating that they comply with phytosanitary requirements and collaborate with transnational packing companies. These producers are responsible for $28 \%$ of the total Mexican avocado production. Many of these producers have adopted a complex quality standard such as US-GAP (good agricultural practices.), Eurep- GAP or Organic. In order to supply uniform and high quality products, these producers have invested in fertilization and irri-

${ }^{2}$ In 1914, the US government established phytosanitary measure that prohibited Mexican avocado exports to the US market (Sánchez, 2007).

${ }^{3}$ On February 5, 1997, the ban on Mexican avocado imports into US was lifted. To allow exports of Mexican avocado to the US, the United States Department of Agriculture requires verification of compliance to the phytosanitary conditions, which is inspected by the Animal and Plant Health Inspection Services. In addition, a continuous program of pest control must be adopted by Mexican producers (Sánchez, 2007).

${ }^{4}$ The following firms are integrated packer/traders: Calavo, West Pak, Empacadora de Aguacates San Lorenzo, Frozavo, Procesadora de Aguacate y Frutas. 
gations systems. The second channel consists of producers that also have a phytosanitary certificate, but sell to large domestic supermarkets or export to Central America. These producers also produce about $28 \%$ of domestic production. Only one out of three of the producers in this channel has adopted a complex quality standard and has invested in fertilization and irrigations systems. As a result, not all of the product complies with the minimum export quality requirements in terms of size, color, and ripeness. The third channel, taking care of $44 \%$ of total domestic avocado production, consists of producers that do not have a phytosanitary certificate. These producers have not invested in fertilization and irrigations systems. The main destination for the avocados of these producers is the small and medium-sized retailers in the domestic market. In Section $\mathrm{V}$ we will elaborate on the explanation of complex quality standards by some but not by other producers.

Chart 1. Different marketing channels

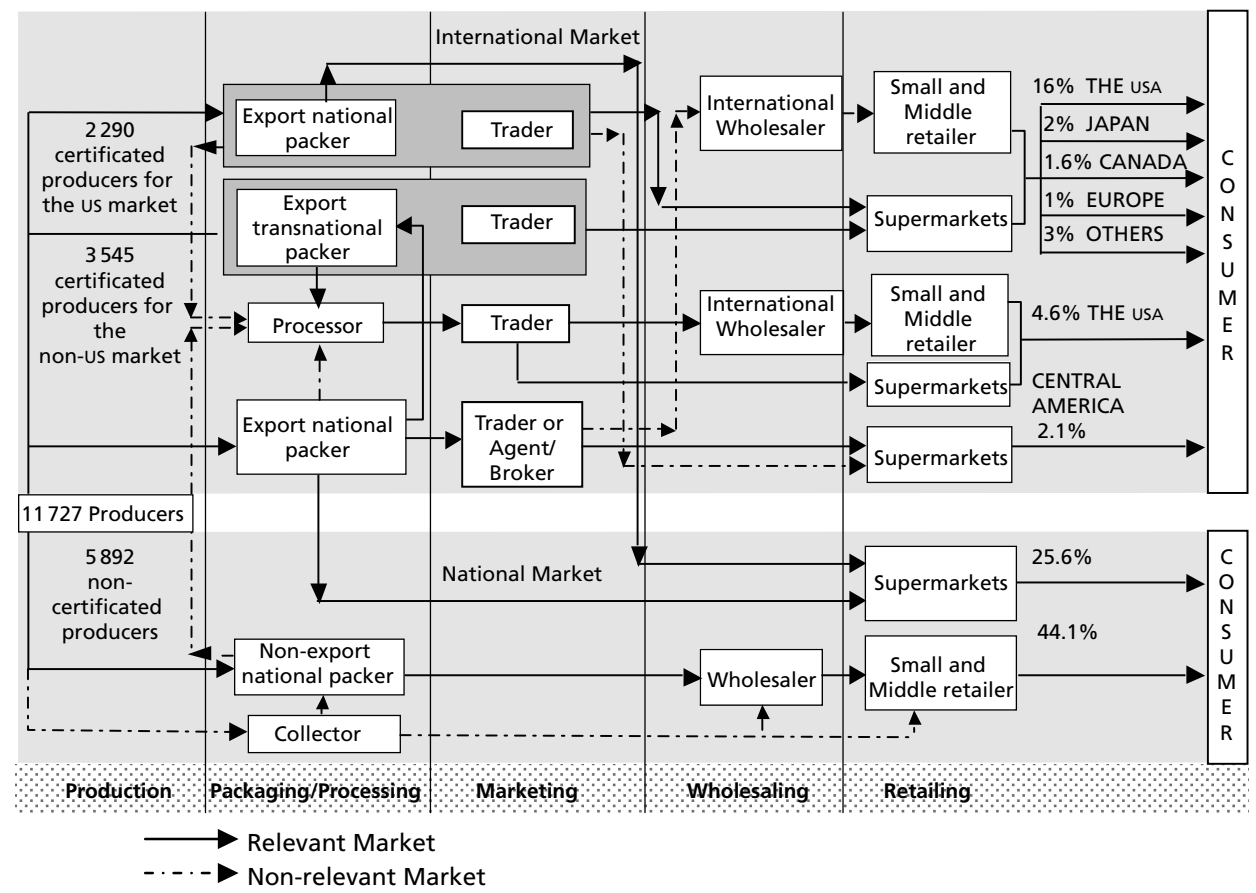

Source: Elaborated from Sanchez (2007) and interviews.

Note: Percentages calculated with respect to total production. 
Chart 2. Michoacán avocado producer characteristics in each marketing channel

\begin{tabular}{|c|c|c|c|c|c|}
\hline $\begin{array}{l}\text { Type of } \\
\text { producer }\end{array}$ & $\begin{array}{l}\text { Number of } \\
\text { producers }\end{array}$ & $\begin{array}{c}\text { Share } \\
\text { of total } \\
\text { production }\end{array}$ & $\begin{array}{l}\text { Type of quality } \\
\text { standard } \\
\text { adopted }\end{array}$ & $\begin{array}{l}\text { Compliance and } \\
\text { investment }\end{array}$ & $\begin{array}{c}\text { Market } \\
\text { destination }\end{array}$ \\
\hline $\begin{array}{l}\text { Certified } \\
\text { producers } \\
\text { for the US } \\
\text { market }\end{array}$ & $\begin{array}{l}2290 \\
(20 \%)\end{array}$ & $28 \%$ & $\begin{array}{l}\text { Complex quality } \\
\text { standards } \\
\text { such as US-GAP, } \\
\text { Eurep- GAP, } \\
\text { Organic }\end{array}$ & $\begin{array}{l}\text { Compliance with } \\
\text { phytosanitary } \\
\text { conditions and } \\
\text { investment in } \\
\text { fertilizers and } \\
\text { irrigation systems }\end{array}$ & $\begin{array}{l}\text { US and other } \\
\text { foreign markets } \\
\text { such as Japan, } \\
\text { Canada and } \\
\text { Europe }\end{array}$ \\
\hline $\begin{array}{l}\text { Certified } \\
\text { producers } \\
\text { for non-us } \\
\text { markets }\end{array}$ & $\begin{array}{c}3545 \\
(30 \%)\end{array}$ & $28 \%$ & $\begin{array}{l}\text { One of each } \\
\text { three producers } \\
\text { adopts complex } \\
\text { quality standard }\end{array}$ & $\begin{array}{l}\text { One of each three } \\
\text { producers compliance } \\
\text { with phytosanitary } \\
\text { conditions and } \\
\text { investment in } \\
\text { fertilizers and } \\
\text { irrigation systems }\end{array}$ & $\begin{array}{l}\text { Mainly supplying } \\
\text { domestic } \\
\text { supermarkets; } \\
\text { limited export to } \\
\text { Central America }\end{array}$ \\
\hline $\begin{array}{l}\text { Non- } \\
\text { certified } \\
\text { producers }\end{array}$ & $\begin{array}{c}5892 \\
(50 \%)\end{array}$ & $44 \%$ & $\begin{array}{l}\text { No quality } \\
\text { standards }\end{array}$ & $\begin{array}{l}\text { No compliance } \\
\text { with phytosanitary } \\
\text { conditions and } \\
\text { no investment } \\
\text { in fertilizers and } \\
\text { irrigation systems }\end{array}$ & $\begin{array}{l}\text { Small and } \\
\text { medium-sized } \\
\text { retailers in the } \\
\text { domestic market }\end{array}$ \\
\hline Total & $\begin{array}{c}11727 \\
(100 \%)\end{array}$ & $00 \%$ & & & \\
\hline
\end{tabular}

Source: Ramos (2007), Sánchez, (2007), and interviews.

\section{The packers}

Traditionally the function of the avocado packers has been to collect, pack, and distribute the fruits. This function includes activities like purchasing, transporting from orchard to packaging-house, sorting, and transporting from packaginghouse to wholesale or retail customers. However, the specialization level of the trading activity differs in terms of the marketing channel. In the domestic marketing channel, the packer carries out the purchase process without a further quality control, and therefore, the maximum shelf life of the product is approximately two weeks (Dorantes, Parada and Ortiz, 2004). In contrast, in the international marketing channel, a specialized trading company (or trade department of an integrated trading/packing company) carries out the purchase process based on export quality requirements, and after, the trading activity.

In the Mexican avocado industry, there are approximately 382 packaging-houses (Chart 3). Only 62 of these firms participate in the export channel, 
and only 26 export to US (Sánchez, 2007). Each of these 26 large size packaginghouses sells more than 8000 tons of avocados per year, and is supplied by an average of fifty producers. They are characterized by a high technology level and use of quality systems such as good manufacturing practices. The middle packers sell between 1500 and 8000 tons of avocados a year, and are supplied by a range of twenty to fifty producers. These packers have different technological level for conducting the different activities in the packaging station. Finally, 320 packers with small packaging stations sell less than 1500 tons a year and are supplied by less than twenty producers. They use obsolete technology, sorting the product manually.

Chart 3. Grouping of packaging-houses

\begin{tabular}{|c|c|c|c|c|}
\hline $\begin{array}{l}\text { Number } \\
\text { of } \\
\text { packers }\end{array}$ & $\begin{array}{l}\text { Volume } \\
\text { (tons/year) }\end{array}$ & Technology & $\begin{array}{c}\text { Market } \\
\text { destination }\end{array}$ & $\begin{array}{l}\text { Suppliers } \\
\text { per } \\
\text { packer }\end{array}$ \\
\hline 26 & $\begin{array}{l}>8000 \\
\text { (large } \\
\text { packers) }\end{array}$ & $\begin{array}{l}\text { - Implementation of Good } \\
\text { Manufacturing Practices } \\
\text { - Automatic equipment for cleaning, } \\
\text { sorting, packaging, refrigeration } \\
\text { - Specialized personnel to make } \\
\text { harvesting activity and plan } \\
\text { production needs and distribution } \\
\text { - Cold chain with control atmosphere } \\
\text { containers }\end{array}$ & $\begin{array}{l}\text { The main } \\
\text { market is us. } \\
\text { Also } \\
\text { exporting } \\
\text { to Japan, } \\
\text { Europe, } \\
\text { Canada }\end{array}$ & $\begin{array}{c}\text { More } \\
\text { than } 50\end{array}$ \\
\hline 36 & $\begin{array}{l}1500- \\
8000 \\
\text { (middle } \\
\text { packers) }\end{array}$ & $\begin{array}{l}\text { - Different technological level for } \\
\text { conducting the packaging activities. } \\
\text { - Some packaging-houses use } \\
\text { automatic equipment whereas others } \\
\text { use mechanic equipment or develop } \\
\text { the activities manually } \\
\text { - Some packaging-houses have } \\
\text { specialized personnel, but most cases } \\
\text { employ unskilled personnel } \\
\text { - Cold chain transport }\end{array}$ & $\begin{array}{l}\text { The main } \\
\text { markets } \\
\text { are Central } \\
\text { America and } \\
\text { domestic } \\
\text { supermarkets }\end{array}$ & $20-50$ \\
\hline 320 & $\begin{array}{c}<1500 \\
\text { (small } \\
\text { packers) }\end{array}$ & $\begin{array}{l}\text { - Obsolete technological level } \\
\text { - Sorting is done manually } \\
\text { - No skilled personnel } \\
\text { - No cold chain }\end{array}$ & $\begin{array}{l}\text { The main } \\
\text { markets are } \\
\text { domestic } \\
\text { small and } \\
\text { medium-sized } \\
\text { retailers, and } \\
\text { street markets }\end{array}$ & $\begin{array}{c}\text { Less than } \\
20\end{array}$ \\
\hline
\end{tabular}

Total: 382

Source: Elaborated from Ramos (2007) and interviews. 
Given the high quality requirements in international markets, there has been an increasing differentiation between packers that participate in international channels and those that only service domestic channels. The internationally oriented packers not only use high-tech equipment for sorting and grading avocado, as well as refrigerated storage of the fruits, but also are often vertically integrated with international trading companies. Three integrated packing/trading firms manage $40 \%$ of all exports to Us: Calavo, Mission, and West Pak. All three are subsidiaries of US companies.

\section{Organizations of packers}

Packers have been organized in a number of different organizations, depending on their main destination markets. Three organizations can be distinguished: the Asociación de Productores y Empacadores Exportadores de Aguacate de México (APEAM), the Unión de Empacadores y Comercializadores del Aguacate de Michoacán (UDECAM), and the Unión de Empacadores de Aguacate de Peribán (UEAP). ${ }^{5}$ APEAM is an organization of more than 2290 producers and 26 packers that send their products to the US market. UDECAM is an organization of 61 packaging-houses, some of them are also members of APEAM. UDECAM members export avocado to Japan, Canada, the European Union and Central America. In addition, they sell avocado to different supermarkets in México. UEAP is an organization of 31 packers, all from the Peribán municipality, mainly serving the domestic market (Sánchez, 2007).

APEAM plays a major role in the Mexican avocado industry because it is the only organization that includes both packers and producers. Only members of APEAM are authorized to export avocado to US. As said, APEAM represents the Mexican avocado interest vis-à-vis US authorities. APEAM also covers part of the inspection costs by United States Department of Agriculture (USDA) and Animal and Plant Health Inspection Services (APHIS), inspects both packaging stations and orchards. In addition, APEAM collects market information (prices, stocks, consumer preferences), promotes Mexican avocado in the US market, and introduces a quota system to avoid saturation of the US markets (Sánchez, 2007).

The producers and packers that are members of APEAM have been working closely with government officials to develop the current legislation on

${ }^{5}$ In English: Avocado Producers and Export Packers Association, Union of Michoacan Avocado Packers and Traders, and Union of Periban Avocado Packers, respectively. 
phytosanitary requirements. While only $16 \%$ of total Mexican fresh avocado production is exported to US, the phytosanitary conditions for products exported to the US markets have also become mandatory for producers and packers that only sell in the domestic market (Stanford, 2002). ${ }^{6}$

\section{The role of the government}

In 1994, the North American Free Trade Agreement (NAFTA) was signed by Canada, USA, and México. Under this agreement, Mexican producers were expected to respond to market signals to redirect their activities towards more profitable, labor-intensive exports such as vegetables, fruits, and nuts (De Janvry, Sadoulet and Davis, 1997).

To facilitate producers' adjustment to a market economy, the federal government implemented a subsidy program to increase investment and productivity in the agricultural sector (Cord and Wodon, 2001). Particularly in the Mexican avocado industry, subsidies have been given to cover part of the extra production costs resulting from phytosanitary standards (Sánchez, 2007). In August 1996, the Mexican government established the legal phytosanitary requirements for commercializing avocado. ${ }^{7}$ Although the legislation was based on US phytosanitary regulations for importing avocado, the Mexican government has now ruled that producers for the domestic market should also meet these standards (Stanford, 2002).

In August 1996, the law also established the legal base for a system of governmental phytosanitary control, requiring all avocado producers to enter in the pest control program and obtain certification for their orchards if they intend to market their fruit at regional packaging-houses (Dorantes, Parada and Ortiz, 2004). To implement this norm, the Secretaría de Agricultura, Ganadería, Desarrollo Rural, Pesca y Alimentación (SAGARPA) promoted the creation of two entities: the Juntas Locales de Sanidad Vegetal (JLSV) ${ }^{8}$ and the APEAM. The JLSVs are supported by producers' organizations, and are responsible of verifying and certification of phytosanitary conditions in the orchards.

\footnotetext{
${ }^{6}$ This is not to say that all producers comply with the legislation. Packers targeting the national market do not require their suppliers to be certified.

${ }^{7}$ The law is called NOM-066-FITO-1995, and the authority responsible for implementation is the Secretaría de Agricultura, Ganadería, Desarrollo Rural, Pesca y Alimentación (SAGARPA, 2013).

${ }^{8}$ Plant Safety Municipal Boards.
} 


\section{THE MAIN SUPPLY CHAIN CHALLENGES}

Producers and packers of fruits and vegetables in developing countries are facing a number of supply chain challenges (Jaffee and Henson, 2004; Reardon and Berdegue, 2002; Shepherd, 2005). The main challenges are (1) increased stringency of food safety and phytosanitary standards; (2) a shift from product standards, largely enforced through testing at national borders, towards standards that target processes in the entire chain; (3) a trend to complement statutory standards with private standards such as British Retail Consortium (BRC), EurepGAP, and Safe Quality Food; and (4) the rise of supermarkets in developing countries, which use more centralized purchasing systems and require large volumes of uniform quality.

The introduction of strict phytosanitary requirements for exporting to the US market has led to specific supply chain challenges for the Mexican avocado industry. From the perspective of the packers, three challenges stand out (Ramos, 2007; Sánchez, 2007): enhancing product quality; creating reliable avocado supply (Dirección General Adjunta de Planeación Estratégica, Análisis Sectorial y Tecnologías de la Información, 2014); and improving coordination between supply and demand. In terms of our theoretical framework, these challenges may lead to higher transaction costs. This section will discuss these challenges, while the next section will present the technical and organizational solutions the producers and packers have applied.

\section{Enhancing product quality}

In their ambition to market avocado in the US, producers and packers were faced with a number of uncertainties. As US consumers are more demanding on product quality than Mexican consumers, exporting to that country implies a different quality strategy. For the packer the initial information problem is to find the right product and right producers (those complying with phytosanitary requirements), i.e., screening and selecting costs. At the same time, for the producers, the problems are how to obtain the knowledge and skills to produce high quality avocado, and to signal packers that their product meets the export quality requirements, i.e., coordination costs (Sánchez, 2007). As to the investments needed to enhance product quality, the packer has to invest in more sophisticated sorting and selecting equipment, in refrigerated storage capacity, and in high hygiene packaging facilities. When there are only a small number of producers that can 
supply the demanded quality, the investments by the packer are specific to the relationship with those producers. In addition, when the number of buyers is limited, the investments by the producers are also specific to the sales relations with those buyers.

\section{Creating reliable supply}

When supplying supermarkets in developed countries, deliveries have to be reliable both in quantity (right volume delivered at the right time) and in quality (uniform quality, all complying with a certain standard). In general, supermarkets demand year-round supply of uniform quality and apply rather strict delivery conditions (Reardon et al., 1999). Given the tradition of low quality demand in the domestic market, creating a continuous supply of high quality products for the US markets is a real challenge for export-oriented packers. As more than $70 \%$ of the Mexican avocado producers fall in the small size category (producing less than 50 tons per year), variation in quantity delivered and in product quality has been quite large (Sánchez, 2007). Thus, packers participating in the export channel have a horizontal coordination problem in dealing with many different suppliers. How to obtain avocado in sufficient quantity and with sufficient quality?

\section{Improving coordination in the supply chain}

Coordination among supply chain actors is more critical when targeting the international market compared to the domestic market (Sánchez, 2007). Avocado commercialized in the international market requires higher quality, more uniform quality, consistency in timing and quality of deliveries, long distance transporting, a closed cool chain, and often specialized packaging. Since export as a share of total production is growing rapidly, coordination issues have also gained importance. The information needed to improve coordination in the supply chain refers to consumer demand, retail firm preferences, promotions, market structure (for instance information on competitors), logistics, availability of supply, and quality of supply. Packers play a major role in collecting, processing, distributing, and using this information. However, the packer distributing the information can face opportunistic behavior from the producer (for example, demanding high price for the product when the packer requirements are higher). 


\section{TECHNICAL AND ORGANIZATIONAL SOLUTIONS}

Enhancing product and process quality entails adaptation of business processes, additional investments, improved information exchange, and more coordination between supply chain participants. The introduction of higher quality is associated with more investments in non-redeployable assets. Therefore, one should expect that market governance will be replaced by hybrid forms or vertical integration. In fact, raising quality is not only associated with higher asset specificity, but also with more uncertainty and higher coordination needs.

Packers and producers have implemented a number of technical and organizational solutions to meet the above described supply chain challenges, particularly for meeting the demands of international markets (Bakshi, 2003). Here we focus on three supply chain management practices as solutions for the above described challenges: product standardization as the main solution for enhancing quality, supplier partnership as the main solution for obtaining reliable supply, and information exchange as a solution for the coordination needs in the supply chain. These solutions have had a transaction cost reduction effect.

\section{Enhancing Quality}

The issue of product quality has been strongly related to phytosanitary quality, which is the absence of pests and diseases (Stanford, 2002). Packers targeting the international markets have to comply with a number of phytosanitary requirements: the product must come from certified orchards; the packaging-house should have a registration; and all shipments of avocado must carry origin verification from registered orchards or packaging-houses (Bakshi, 2003). Therefore, the federal government has established the regional system of phytosanitary control that requires all avocado producers to enter the pest control program and obtain certification for their orchards if they intend to market their fruit at regional packaging-houses. For the producers, entering a phytosanitary program requires compliance with technical recommendations issued by visiting inspectors. These inspections are carried out by the JSLVs. Packers recognize the phytosanitary standard (including certification) issued by the JSLVs. Adopting phytosanitary standards, the transaction costs for the packer of verifying whether a producer complies with the phytosanitary requirements are substantially reduced (Salazar-García, Zamora-Cuevas and Vega-López, 2005). The system of certification of orchards based on both the public phytosanitary control program and 
the establishment of the JSLV at the municipal level has reduced uncertainty on the phytosanitary quality and, therefore, has reduced the monitoring transaction costs in the producer-packer trade. In addition, adoption of standards has reduced the negotiating and screening costs.

Federal agencies have indicated that implementing phytosanitary standards and related cultivation methods (including the use of pesticides, fertilizers, and irrigation) increases the production cost by more than 50\%. ${ }^{9}$ In addition, the producer needs to invest in verification and certification. In order to motivate producers to adopt phytosanitary standards, the Mexican federal government has developed a subsidy scheme that represents less than half the additional production cost. Since the legislation on phytosanitary norms was introduced in 1996, an increasing number of producers have been certified. In $2005,50 \%$ of all avocado producers were certified. ${ }^{10}$ While originally only meant for those producers and packers targeting the US market, the legal requirements on phytosanitary conditions now also apply to producers and packers selling in the domestic market. Therefore, an increase in the number of producers with phytosanitary standard has implied a broadening of the sourcing base for the packers.

\section{Reliable supply}

Shifting towards higher value avocado, while at the same time the producer provides a reliable supply has required not only more investment, but also adoption of supplier partnership practice.

Three types of relationship between producers and packers can be found in the avocado industry (Martínez, Espitia and Valenzo, 2013). In the first type, producer and packer as members of APEAM have coincided interests in maintaining a reliable supply for the US market. But they also have joint interest in supporting the public certification program; in gathering and exchanging market information; in regulating supply to prevent saturation of the US market; and in promoting Mexican avocado in the US and other countries. Thus, APEAM association fits the Menard (2004) definition of the hybrid governance structure: pooling resources; maintaining competition among participants; and relying on relational governance to obtain mutual gains, establish order, and resolve conflicts.

\footnotetext{
${ }^{9}$ For the inspection services of USDA/APHIS, Mexican avocado producers and packers pay a fixed fee of USD 0.08 per pound of product. APEAM is responsible for collecting and paying out these fees.

${ }^{10}$ Information obtained from the Comité Estatal de Sanidad Vegetal (CESV) of Michoacán.
} 
The second type of relationship consists of packers and producers of specialty products complying with US and European standards on food safety, good agricultural practice, and organic produce standards, in addition to phytosanitary standard. Given a higher uncertainty (or higher information requirements) and asset specificity in these specialty product supply chains, a contractual relationship will be chosen (Raynaud, Sauvee and Valceschini, 2005). Based on the interviews, a particular case of partnership is identified between a transnational packaging-house with a very large producer (360 ha) to grow and market organic avocado. As producing organic avocado is approximately 50\% more expensive than producing regular avocados, shifting to organic produce poses a transactional risk due to the specific investments the producer has to make. The packer has reduced this risk by making credible commitments in the form of providing credit as well as technical advice. The packer has indicated that this partnership with the large producer has important benefits because of lower coordination costs in sourcing sufficient supplies.

The third type of partnership consists of producers financially participating in a packaging-house. The interviews revealed one particular case of an export packaging-house owned by 11 producers. These owner-suppliers provide $27 \%$ of the avocado packed by the company. The quality of produce supplied by the owners is higher than that of the other 90 suppliers. The owners have agreed that they all obtain US-GAP and Eurep- GAP certification. The packaging-house is putting much effort into providing technical assistance to its owner-suppliers in order for them to comply with current and future product and process requirements. In addition, the packing company continuously invests in keeping its installations as well as its workers' skills up to meeting the requirements of foreign quality certification programs. In sum, to obtain a reliable supply of high quality products, packers selling in the international market have followed different organizational strategies. Both bilateral and multilateral partnerships between producers and packers can be found in the high quality segments of the Mexican avocado industry (Martínez, Espitia and Valenzo, 2013). In addition, the Mexican government is financially supporting producers to adopt the cultivation practices needed to meet phytosanitary standards.

\section{Coordination in the supply chain}

To improve coordination, packers have followed two strategies: vertical integration into trading, and forming partnerships with trading companies. As export 
avocados are sold mainly through supermarkets, it is the policies of those foreign supermarkets that put high pressure on supply chain management. Supermarkets in general have high demands in terms of delivery conditions, logistics, promotions, and product quality. Information about these requirements is crucial for efficient planning and equipment use by the packers. In order to get this information, most packers supplying international markets have integrated with trading companies (Chart 1). These trading companies have direct contact with foreign customers for obtaining information on retail demand, product quality (Martínez, Espitia and Valenzo, 2013), and required quantity, available stocks, etc. Some of the export transnational packaging-houses are subsidiaries of major US fresh produce trading companies. ${ }^{11}$ While some export national packers have also integrated into the trading activity, most of them just sell to the foreign-owned integrated packing-trading companies. By selling to the foreign-owned packers, the domestically owned packaging-houses do not have to bear the market risk present in the international markets, and do not bear the risk of delayed payment by the retail customers. The foreign-owned packers/traders have a reputation of paying immediately (Sánchez, 2007).

The other option for packers is to form partnerships with particular buyers in order to get information about retail demand and promotions. This information can greatly support joint planning activities (Valenzo, Galeana and Martínez, 2015).

To sum up, information exchange has played a relevant role not only in communicating product requirements to producers (thus coordinating the quality produced with the quality demanded), but also in reducing the environmental uncertainty of demand quantities. To get access to crucial customer information, export packers have integrated into trading activities.

\section{Supply Chain Management by packers}

In recent decades, packers have taken up new functions, particularly when they became participants in international marketing channels. The role of the packer has broadened, to include harvesting, selecting and sorting, cleaning, refrigerated storage, quality control, labeling and cooled transport (Sánchez, 2007). Chart 4 lists the activities of the packer working on the national market, and those of the packers selling on the international market. Given the high product quality and

\footnotetext{
${ }^{11}$ These are Calavo, Mission, West Pak, and Fresh Direction.
} 
phytosanitary requirements of the export markets, packers working in the international marketing channel have enhanced their activities guaranteeing product quality control and reliable supply, and improving coordination between several actors in the supply chain.

Chart 4. Activities of the packer

\begin{tabular}{|c|c|c|}
\hline Main activities & $\begin{array}{l}\text { Activities of packer selling } \\
\text { mainly in domestic market }\end{array}$ & $\begin{array}{l}\text { Activities of packer selling in } \\
\text { foreign market }\end{array}$ \\
\hline Harvesting & $\begin{array}{l}\text { - Unskilled harvest workers } \\
\text { not employed by packer } \\
\text { - Main practice: "al parar" }\end{array}$ & $\begin{array}{l}\text { - Skilled harvest workers } \\
\text { employed by packer or } \\
\text { specialized companies } \\
\text { - Main practice: "al corte" }\end{array}$ \\
\hline $\begin{array}{l}\text { Transport from } \\
\text { orchard to packing } \\
\text { station }\end{array}$ & Transport by packer & Transport by packer \\
\hline $\begin{array}{l}\text { Inside the packing } \\
\text { station }\end{array}$ & $\begin{array}{l}\text { - No cleaning of fruit } \\
\text { - Limited sorting and } \\
\text { selection } \\
\text { - Sorting by hand } \\
\text { - No packaging } \\
\text { - No labelling } \\
\text { - No refrigeration } \\
\text { - No tracing and tracking }\end{array}$ & $\begin{array}{l}\text { - Cleaning of fruit } \\
\text { - Elaborate sorting and selection } \\
\text { (by size, weight, ripeness) } \\
\text { - Automated sorting } \\
\text { - Specialized packaging (special } \\
\text { cardboard box to regulate } \\
\text { temperature) } \\
\text { - Labelling } \\
\text { - Refrigeration } \\
\text { - Tracking and tracing }\end{array}$ \\
\hline Trading/selling & By specialized traders & $\begin{array}{l}\text { Mainly by integrated packer/ } \\
\text { trader }\end{array}$ \\
\hline
\end{tabular}

Source: Dorantes, Parada and Ortiz (2004), Sánchez (2007) and interviews.

To summarize, packers selling mainly in the domestic market do not put much effort in quality improvements and quality control. For the packers for the international markets, however, the issue of enhancing product quality and maintaining the quality level throughout the supply chain is a major objective. All harvesting, sorting and selection, cleaning, storing, and transport activities are geared towards the quality ambition. These activities also require specialized knowledge and equipment at the packaging station, as well as harvesting by skilled teams. By careful selection, cleaning and refrigeration (including cold chain transport), the shelf life of the export avocado is extended to about forty days. 


\section{CONCLUSIONS}

The present research analyzed how packers of fresh product can play a major role in setting particular quality standards, promoting a reliable supply, and enhancing product quality by exchanging information between producers and customers.

We have presented a qualitative analysis of the technical and organizational solutions that packers and producers in the Mexican avocado industry have introduced to deal with new supply chain challenges. As a result of changes in (international) market opportunities, avocado producers and packers face a number of supply chain challenges. The main challenges are low quality, unreliable supply, and a lack of supply chain coordination. In order to meet these challenges, a restructuring of the avocado supply chain has taken place, including the entrance of US capital into the Mexican packing industry, introducing phytosanitary standards, establishing new types of producer-packer partnerships, and facilitating information exchange. These technical and organizational changes can be considered as a response to the rising transaction costs that resulted from higher quality demands.

The problem of low avocado quality and the related uncertainty problem for the packer about how to fit the product quality and safety conditions according to the international market requirements and measure producer compliance to quality and safety requirements have been solved by several strategies. First, based on the packer requirements, $50 \%$ of the producers have adopted a phytosanitary standard. This standard has facilitated product compliance. Second, packers and producers have lobbied with the government to develop and implement a certification scheme for all avocado producers, thus reducing diversity among producers and products. The actual inspection and certification is done by the Juntas Locales de Sanidad Vegetal, a public-private partnership. As result of the certification system monitoring costs faced by the packer are reduced.

The problem of obtaining reliable supply has been solved when some packers have entered into partnership with producers, either bilaterally or multilaterally (within organizations). These partnerships are a form of relational governance that reduce transaction costs related to difficult performance measurement and high coordinated response for high quality requirements; for example when packers demand product that satisfies US-GAP, Eurep- GAP, or Organic certification. 
The coordination problem due to international market uncertainty conditions has been solved by the packers by forward integration into trading companies. By integrating, they are now able to obtain detailed information on retail customer demand, and are better able to coordinate their purchasing activities with their marketing activities. This vertical integration has also solved the problem of asset specificity in the transaction between packer and traders for the US market.

In meeting the new international market opportunities for Mexican avocado, the packers have played a dominant role in obtaining the supply chain management goals of efficiency and market responsiveness. Individually, the packaging-houses have upgraded their equipment, integrated with traders to obtain critical market information, and entered into partnerships with producers to improve their sourcing. In addition, organizations of packer and producers have established transaction cost reducing procedures for producer-packer trade, and have lobbied the government for an enabling institutional environment.

Examining transactions within a supply chain context is a current topic in the TCE literature, and particularly, the role that packers play enhancing the Mexican avocado export will continue being a valid topic. As mentioned in the present study, Mexican avocados exported to the US markets compete with fruit from California and from Chile. In the future, at least two particular reasons might continue promoting adoption of supply chain management practices. The first reason is increasing product for the international markets, and the second reason is effects of climate change. For both reasons, packers require to promote the practices to reduce their exposure to supply side transaction risk can affect their exposure to demand side.

\section{APPENDIX. QUESTIONS FOR CASE STUDY}

\begin{tabular}{|l|l|}
\hline \multicolumn{2}{|l|}{ Respondent information } \\
\hline 1. What is your position in the company/organization? & \\
\hline 2. How long have you been working in this company? & \\
\hline 3. How long have you been working in this position? & \\
\hline
\end{tabular}

\section{Industry and market characteristics}

4. What different market channels can be identified in the avocado industry in Michoacán? 


\begin{tabular}{|l|l|}
\hline $\begin{array}{l}\text { 5. How many producers participate in each market } \\
\text { channel? }\end{array}$ & \\
\hline $\begin{array}{l}\text { 6. How many packers and export packers participate } \\
\text { in each market channel? }\end{array}$ & \\
\hline $\begin{array}{l}\text { 7. How many traders participate in each market } \\
\text { channel? }\end{array}$ & \\
\hline $\begin{array}{l}\text { 8. How many associated and non-associated produ- } \\
\text { cers and packers participate in each market } \\
\text { channel? }\end{array}$ & \\
\hline $\begin{array}{l}\text { 9. How much product is marketed in the different } \\
\text { channels? (international and national market: } \\
\text { supermarket and middle and small retailers) }\end{array}$ & \\
\hline
\end{tabular}

\begin{tabular}{|l|l|}
\hline \multicolumn{2}{|l|}{ Transactional problems } \\
\hline 10. Are there problems about product quality? & \\
\hline 11. Are there problems about stable product supply? & \\
\hline $\begin{array}{l}\text { 12. Are there problems about planning production } \\
\text { and fulfillment of the buyer's order? }\end{array}$ & \\
\hline
\end{tabular}

\section{Supply Chain Management Practices}

13. What are the activities and investments taken by the producers in order to improve product quality?

14. What are the activities and investments taken by the packers in order to achieve a stable product supply with the required quality?

15. What are the activities and investments taken by the packers with the producers in order to develop a supplier-partnership relation?

16. What are the activities implemented by the packers with the trader in order to synchronize the production? (planning production, stock capacity, processing activities, and estimation of sales forecasting)

17. What percentage of the producers complies with phytosanitary and product quality activities?

18. What percentage of the packers develops a supplier-partnership relation with producers?

19. What percentage of the packers receives information from traders in order to synchronize the production? 


\begin{tabular}{|l|l|}
\hline Governance structure \\
\hline $\begin{array}{l}\text { 20. What are the different arrangements between } \\
\text { producer and packer? (spot market, short } \\
\text { arrangement, large arrangement, verbal arrange- } \\
\text { ment, and ownership) }\end{array}$ & \\
\hline $\begin{array}{l}\text { 21. What are the different arrangements between } \\
\text { packer and trader? (spot market, short term } \\
\text { contract, large term contract, verbal arrangement, } \\
\text { and ownership) }\end{array}$ & \\
\hline 22. Is a certain arrangement preferred? and why? & \\
\hline $\begin{array}{l}\text { 23. What are the conditions included in these arrange- } \\
\text { ments? }\end{array}$ & \\
\hline $\begin{array}{l}\text { 24. Is a certain arrangement preferred by associated and } \\
\text { non-associated producers and packers? }\end{array}$ & \\
\hline
\end{tabular}

\begin{tabular}{|l|l|}
\hline \multicolumn{2}{|l|}{ Association } \\
\hline $\begin{array}{l}\text { 25. How many associations exist in the avocado sector } \\
\text { in Mexico? }\end{array}$ & \\
\hline 26. Who are the types of members in each association? & \\
\hline 27. What are the functions in each association? & \\
\hline 28. What are the members' obligations and rights? & \\
\hline
\end{tabular}

\section{REFERENCES}

Artz, Kendall W., and Brush, Thomas H. (2000). Asset specificity, uncertainty and relational norms: an examination of coordination costs in collaborative strategic alliances. Journal of Economic Behavior \& Organization, 41, pp. 337-362.

Bakshi, Nishita (2003). Sanitary and Phytosanitary Measures: The Case of Mexican Avocados. MSc. thesis, Virginia Polytechnic Institute and State University. [online] Available at: http://scholar.lib.vt.edu/theses/available/etd-07212003164121/unrestricted/thesis.pdf. [Accessed on October 05, 2014]

Barrat, Mark, and Oliveira, Alexander (2001). Exploring experiences of collaborative planning initiatives. International Journal of Physical Distribution and Logistics Management, 31 (4), pp. 266-289.

Baumol, William J. (1952). The transactions demand for cash: An inventory theoretic approach. Quarterly Journal of Economics, 66 (4), pp. 545-556.

Coase, Ronald H. (1937). The nature of the firm. Economica, 4 (16), pp. 386-405. 
Cord, L., and Wodon, Q. (2001). Do agricultural programs in Mexico alleviate poverty? Evidence from the ejido sector. Cuadernos de Economía, 38 (114), pp. 239-256.

Das, T. K., and Teng, Bing-Shen (1998). Between trust and control: developing confidence in partner cooperation alliances. Academy of Management Review, 23 (3), pp. 491-512.

De Janvry, Alain; Sadoulet, Elisabeth, and Davis, Benjamin (1997). NAFTA and agriculture: an Early Assessment. Investigación Económica, 57 (221), pp. 13-60.

Dirección General Adjunta de Planeación Estratégica, Análisis Sectorial y Tecnologías de la Información (2014). Panorama del aguacate. Financiera Nacional de Desarrollo, México. Available at: www.financierarural.gob.mx/informacionsectorrural/Panoramas/Panorama\%20Aguacate\%20(abr\%202014).pdf. [Accessed on Octuber 05, 2014]

Dirección General de Industrias Básicas (2012). Monografía del sector de aguacate en México: Situación actual y oportunidades. Secretaría de Economía, México. Available at: www.economia.gob.mx/files/Monografia_Aguacate.pdf. [Accessed on Octuber 05, 2014]

Dorantes, Lidia; Parada, Lidia, and Ortiz, Alicia (2004). Chapter XXX: Post-Harvest Operation. AGST/Food and Agriculture Organization of the United Nations. [online] Available at: www.fao.org/inpho/content/compend/text/ch30/ch30.htm. [Accessed on January 20, 2011]

Duffy, Rachel, and Fearne, Andrew (2004). The impact of supply-chain partnerships on supplier performance in the UK fresh-produce industry. In: C.J.M. Ondersteijn, J.H.M. Wijnands, R.B.M. Huirne, and O. van Kooten (eds.). Quantifying the agri-food supply chain. The Netherlands: Springer, pp. 223-238.

Dyer, Jeff H., and Singh, Harbir (1998). The relational view: Cooperative strategy and sources of interorganizational competitive advantage. Academy of Management Review, 23 (4), pp. 660-679.

Evans, Edward, and Nalampang, Sikavas (2006). World, US and Florida Avocado Situation and Outlook. IFAS Extension, University of Florida. [online] Available at: http://edis.ifas.ufl.edu. [Accessed on January 20, 2010]

FAOSTAT (2013). FAOSTAT Agriculture trade data. Roma, FAO. [online] Available at: http:// faostat.fao.org/site/406/default.aspx. [Accessed on June 10, 2013]

Grover, Varun, and Malhotra, Manoj K. (2003). Transaction Cost Framework in Operations and Supply Chain Management Research: Theory and Measurement. Journal of Operations Management, 21 (4), pp. 457-473.

Hammoudi, Abdelhakim; Hoffmann, Ruben, and Surry, Yves (2009). Food Safety Stan- 
dards and Agri-Food Supply Chains: An Introductory Overview. European Review of Agricultural Economics, 36 (4), pp. 469-478.

Holleran, Erin; Bredahl, Maury E., and Zaibet, Lokman (1999). Private incentives for adopting food safety and quality assurance. Food Policy, 24 (6), pp. 669-683.

Jaffee, Steve, and Henson, Spencer (2004). Standards and Agro-Food Exports from Developing Countries: Rebalancing the Debate. World Bank Policy Research Working Paper 43. [online] Available at: http://english.boaoforum.org/u/cms/ www2/201109/07143133gk45.pdf . [Accesed on 05, 2014]

Joskow, Paul L. (1985). Vertical Integration and Long-term contracts: The case of CoalBurning Electric Generating Plants. Journal of Law, Economics, \& Organization. 1 (1), pp. 33-80.

Kannan, Vijay R., and Tan, Keah- Choon (2005). Just in time, total quality management, and supply chain management: understanding their linkages and impact on business performance. Omega: The International Journal of Management Science, 33 (2), pp. 153-162.

Kulp, Susan; Ofek, Elie, and Whitaker, Jonathan (2003). Supply Chain Coordination: How companies leverage information flows to generate value. In: T. P. Harrison, H. L. Lee, and J. J. Neale (eds.). The practice of supply chain management: where theory and application converge. The Netherlands: Kluwer Academic, pp. 91-108

Kumar, Nirmalya; Scheer, Lisa K., and Steenkamp, Jan-Benedict E. M. (1995). The effects of perceived interdependence on dealer attitudes. Journal of Marketing Research, 32 (3), pp. 348-356.

Martínez, Jaime; Espitia, Irma, and Valenzo, Marco (2013). Análisis de las cadenas de valor de las empresas exportadoras de aguacate. Revista Nicolaita de Estudios Económicos. 8 (1), pp. 96-125.

Menard, Claude (2004). The economics of hybrid organizations. Journal of Institutional and Theoretical Economics, 160 (3), pp. 345-376.

Noordewier, Thomas; John, George, and Nevin, John R. (1990). Performance Outcomes of Purchasing Arrangements in Industrial Buyer-Vendor Relationships. Journal of Marketing, 54 (4), pp. 80-93.

Ortiz, Salvador (2007). Un largo y sinuoso camino. Revista APEAM, 3 (13), pp 2-13.

Power, Damien (2008). Capability and Practice in Procurement Collaboration: A Vendor's Perspective of Benefits. Operation and Supply Chain Management, 1 (2), pp. 72-84.

Pyke, David F., and Johnson, M. Eric (2003). Sourcing strategy and supplier relationships: Alliances versus e-procurement. In: T. P. Harrison, H. L. Lee, and J. J. 
Neale (eds.). The practice of supply chain management: where theory and application converge. The Netherlands: Kluwer Academic Publishers Group, pp. 77-89.

Ramos, José-Alonso (2007). Perspectivas de la red aguacate para el 2007. Morelia: Fideicomisos Instituidos en Relación con la Agricultura (FIRA), Banco de México. Raynaud, Emmanuel; Sauvee, Loic, and Valceschini, Egizio (2005). Alignment between Quality Enforcement Devices and Governance Structures in the Agro-food Vertical Chains. Journal of Management and Governance, 9 (1), pp. 47-77

Reardon, Thomas, and Barrett, Christopher B. (2000). Agroindustrialization, globalization, and international development, an overview of issues, patterns, and determinants. Agricultural Economics, 23 (3), pp. 195-205.

Reardon, Thomas, and Berdegue, Julio A. (2002). The Rapid Rise of Supermarkets in Latin America: Challenges and Opportunities for Development. Development Policy Review, 20 (4), pp. 371-388.

Reardon, Thomas; Codron, Jean-Marie; Busch, Lawrence; Bingen, James, and Harris, Craig (1999). Global Change in Agrifood Grades and Standards: Agribusiness Strategic Responses in Developing Countries. International Food and Agribusiness Management Review, 2 (03/04), pp. 421-435.

Rindfleisch, Aric, and Heide, Jan B. (1997). Transaction Cost Analysis: Past, Present, and Future Applications. Journal of Marketing, 61 (4), pp. 30-54.

Ruben, Ruerd; van Boekel, Martinus; van Tilburg, Aad, and Trienekens, Jacques (eds.) (2007). Tropical Food Chains, The Netherlands, Wageningen Academic Publishers.

SAgARPA (2013). Servicio de Información Agroalimentaria y Pesquera. Available at: www.siap.gob.mx/index.php?option=com_content\&view=article\&id=11\&Item $\mathrm{id}=16$. [Accessed on January 20, 2013]

Salazar-García, Samuel.; Zamora-Cuevas, Luis., and Vega-López, Ricardo (2005). Actualización sobre la industria del aguacate en Michoacán, México. [online] Available at: http://avocadosource.com/CAS_Yearbooks/CAS_87_2004-2005/ CAS_2004-05_V87_PG_045-054.pdf. [Accessed on Octuber 05, 2014]

Sánchez, Guillermo (2007). El cluster del aguacate de Michoacán. Sistema de Inteligencia de Mercados. Morelia: Fundación Produce Michoacán.

Shepherd, Andrew W. (2005). The implications of supermarket development for horticultural farmers and traditional marketing systems in Asia. Kuala Lumpur. FAO/ AFMA/ FAMA Regional Workshop on the Growth of Supermarkets as Retailers of Fresh Produce. [online] Available at: www.fao.org/fileadmin/user_upload/ags/ publications/asia_sups.pdf . [Accessed on January 20, 2011] 
Simatupang, Togar M., and Sridharan, Ramaswani (2004). Benchmarking Supply Chain Collaboration: an Empirical Study. Benchmarking: An International Journal, 11 (5), pp. 484-503.

Spriggs, John; Hobbs, Jill, and Fearne, Andrew (2000). Beef producer attitudes to coordination and quality assurance in Canada and the UK. International Food and Agribusiness Management Review, 3 (1), pp. 95-109.

Stanford, Lois (1998). Mexico's Empresario in Export Agriculture: Examining the Avocado Industry of Michoacan. Meeting of the Latin American Studies Association, The Palmer House Hilton Hotel, Chicago, Illinois. [online] Available at: http://168.96.200.17/ar/libros/lasa98/Stanford.pdf. [Accessed on January 20, 2008]

- (2002). Constructing quality: the political economy of standards in Mexico's avocado industry. Agriculture and Human Values, 19 (4), pp. 293-310.

Tobin, James (1956). The Interest-Elasticity of Transactions Demand for Cash. Review of Economics and Statistics, 38 (3), pp. 241-247.

Van der Vorst, Jack G. A. J.; da Silva, Carlos A., and Trienekens, Jacques H. (2007). Agro-industrial supply chain management: concepts and applications, Agricultural Management, Marketing and Finance Occasional Paper 17, FAO.

Van der Vorst, Jack G. A. J.; van Dijk, Stephan J.; and Beulens, Adrie. J. M. (2001). Leagile supply chain design in food industry; an inflexible poultry supply chain with high demand uncertainty. International Journal on Logistics Management, 12 (2), pp. 73-85.

Van Plaggenhoef, Wijnand (2007). Integration and self regulation of quality management in Ducht agrifood supply chains. Wageningen: Wageningen Academic Publishers.

Valenzo, Marco; Galeana, Evaristo, and Martínez, Jaime (2015). Competitividad y Supply Chain Management en la Industria Exportadora de Aguacates en Mexico. Revista Internacional Administracion \& Finanzas, 8 (2), pp. 1-19.

Williamson, Oliver E. (1979). Transaction-Cost Economics: The Governance of Contractual Relations. Journal of Law and Economics, 22 (2), pp. 233-261.

(1985). The Economic Institutions of Capitalism: Firm, Markets, and Relational Contracting. New York: The Free Press.

(1991). Comparative Economic Organization: The Analysis of Discrete Structural Alternatives. Administrative Science Quarterly, 36 (2), pp. 269-296. 